\title{
Effect of Oxygen Supply on Flavor Formation During Continuous Alcohol-free Beer Production: A Model Study
}

\author{
Radek Lehnert, Michal Kuřec, and Tomáš Brányik, ${ }^{1}$ Department of Fermentation Chemistry and Bioengineering, \\ Institute of Chemical Technology, Prague, Czech Republic; and José A. Teixeira, Centro de Engenharia Biológica, \\ Universidade do Minho, Campus de Gualtar, Braga, Portugal
}

\author{
ABSTRACT \\ J. Am. Soc. Brew. Chem. 66(4):233-238, 2008
}

The influence of oxygen supply on the formation and conversion of the most important flavor compounds during continuous, alcohol-free beer production was studied in a complex model medium. The medium contained inorganic salts, nutrients, and aldehydes (hexanal, 2-methyl propanal, 3-methyl butanal, and furfural) and mimicked real brewery wort, with the advantage of a constant composition. Fermentation experiments were carried out in a continuously operating gas-lift reactor, with brewing yeast immobilized on spent grains. The formation (ethanol, higher alcohols, esters, vicinal diketones, and acetaldehyde) and reduction (aldehydes) of flavor-active compounds at different aeration rates were observed. The results suggest that the oxygen supply represents an influential tool for controlling the degree of fermentation and flavor formation carried out by an immobilized biocatalyst. Under optimal oxygen supply conditions in the continuously operating gas-lift reactor, it was possible to obtain a fermented model medium with a composition approaching that of commercial alcohol-free beers produced by batch process.

Keywords: Alcohol-free beer, Beer flavor, Continuous reactor, Immobilized cell, Oxygen supply

\section{RESUMEN}

La influencia del suministro de oxígeno en la formación y la reconversión de los más importantes compuestos del sabor durante la producción continua de la cerveza sin alcohol se estudió en un complejo modelo mediano. El medio contenida sales inorgánicas, nutrientes, y de aldehídos (hexanal, 2-metil propanal, 3-metil butanal, y furfural) y imitado mosto del cervecería, con la ventaja de una composición constante. Experimentos de fermentación se llevaron a cabo en un reactor cíclico de gas de operación continuo, con levadura cervecero inmovilizada en grano gastado. La formación (etanol, alcoholes superiores, ésteres, dicetonas vecinales, y acetaldehído) y la reducción (aldehídos), de sabor-activo compuestos en diferentes tipos de aireación se observaron. Los resultados sugieren que el suministro de oxígeno representa un influyente herramienta para controlar el grado de fermentación y el formación de sabor llevadas a cabo por un inmovilizado biocatalizador. Con el óptimo suministro de oxígeno en condiciones del reactor cíclico de gas de operación continuo, es posible obtener un modelo de medio fermentado con una composición próxima a la de comerciales cervezas sin alcohol producida por proceso discontinuo.

Palabras claves: Cerveza sabor, Cerveza sin alcohol, Inmovilizados célula, Reactor continuo, Suministro de oxígeno

In EU countries, a beer is considered alcohol-free when its ethanol content does not exceed $0.5 \%$ by volume $(3.945 \mathrm{~g} / \mathrm{L})$. Although still representing a minor product of the brewing industry, the increasing market share of alcohol-free beer reflects the global trend toward healthier lifestyles. There are two main strategies of its production. One is based on the removal of alcohol from regular

\footnotetext{
${ }^{1}$ Corresponding author. Department of Fermentation Chemistry and Bioengineering, Institute of Chemical Technology, Technická 5, 16628 Prague, Czech Republic. E-mail: tomas.branyik@vscht.cz; Phone: +420 220444 126; Fax: +420 220445051.
}

doi:10.1094/ASBCJ-2008-0910-01

(C) 2008 American Society of Brewing Chemists, Inc. beer by dialysis, reverse osmosis, vacuum distillation, or evaporation (18). This approach requires special equipment for alcohol removal, which increases both investment and operation costs. The other strategy encompasses methods of suppressed alcohol formation under controlled conditions. The production of alcohol-free beer using immobilized yeast cell systems is a method of controlled fermentation that uses short contact between immobilized yeasts and wort. Continuous alcohol-free beer fermentation can outperform rival technologies in aspects such as productivity, investment, and operating costs. However, it is essential that the continuous system produces a final product that is competitive in terms of sensorial quality.

Alcohol-free beers usually are characterized by worty off-flavors and lack of the pleasant fruity (estery) aroma found in regular beers. Such defects may stem from the fermentation procedure, which fails both to reduce the chemical compounds responsible for the worty off-flavor and to produce fusel alcohols and esters.

It has been theorized that wort carbonyls contribute to the unpleasant worty taste of alcohol-free beers $(11,23)$. However, yeast metabolism is known to reduce these substances to less flavoractive ones (22). The reduction of wort aldehydes is crucial in alcohol-free beer production (25). Although wort aldehyde reduction during batch fermentations is relatively rapid (11), at the speed of the limited fermentation in continuous systems it may not be sufficient. However, a compromise between alcohol formation and carbonyl reduction can be found by optimizing the process parameters of continuous alcohol-free beer production $(11,32)$.

Several alcohols other than ethanol are formed in beer during fermentation, among which $n$-propanol, isobutanol, and amyl alcohols (2-methyl and 3-methyl butanol) contribute most significantly to beer flavor. Higher alcohol formation in continuously fermented beers can be well balanced by the choice of an appropriate yeast strain $(19,26)$, wort composition, fermentation conditions (aeration, temperature, and residence time), immobilization method, and reactor design (21,37). Most of these interventions are based on the stimulation of growth intensity (e.g., dissolved oxygen concentration and temperature enhancing higher alcohol formation) $(7,29)$. Proper higher alcohol formation also is important for sufficient ester synthesis.

The synthesis of aroma-active esters by yeast is of great importance because these esters represent the largest group of flavoractive compounds in beer. Beer esters can be divided into two main groups. The first group contains acetate esters such as ethyl acetate (fruity, solvent-like), isoamyl acetate (banana), and phenylethyl acetate (roses, honey, apple). The second group of esters contains the so-called ethyl or medium-chain fatty acid esters (e.g., ethyl caproate and ethyl caprylate [both apple-like]) (33). Two factors are fundamentally important for the rate of ester formation: the availability of the two substrates (acetyl/acyl-CoA and fusel alcohols) and the activity of enzymes (mostly alcohol acyltransferases) involved in the formation of esters (16). Consequently, control of ester formation is difficult due to the many factors involved in the regulation of enzyme activity or substrate availability.

Perhaps the most important impact on ester formation in continuous systems is aeration $(31,35)$. Although ethanol production 
is an anaerobic process, some oxygen is essential for several biosynthetic pathways, such as for unsaturated fatty acids, heme, sterols, pyrimidines, and deoxyribonucleotides (30). Therefore, a knowledge of volumetric oxygen mass transfer coefficients $\left(k_{\mathrm{L}} a\right)$ under real fermentation conditions is indispensable to ensure optimum oxygen supply into bioreactors, which results in high fermentation capacity and balanced product flavor.

Fermentation experiments were carried out in a continuously operating gas-lift reactor (GLR), with brewing yeast immobilized on spent grains, a brewing by-product that recently has been applied (e.g., as a carrier for immobilized cell technologies) $(1,5)$ and raw material for bioethanol production (28). To study the influence of oxygen supply on formation and conversion of the most important flavor compounds, real wort (its preparation in a 40-L working volume brewhouse at the Institute of Chemical Technology [ICT], Prague, is not sufficiently reproducible) was simulated by a defined model medium with constant composition. The results were used in the adjustment of process parameters during the following study of continuous, real alcohol-free beer production.

\section{EXPERIMENTAL}

\section{Microorganisms and Medium}

A bottom-fermenting brewing yeast strain (Saccharomyces cerevisiae subsp. carlsbergensis) supplied by UNICER (Bebidas de Portugal, S.A., S. Mamede de Infesta, Portugal) was used throughout the experiments. The yeast was cultivated in a complex model medium (CMM) that mimicked the wort composition used for alcohol-free beer production. The composition of CMM was $5 \mathrm{~g}$ of $\mathrm{KH}_{2} \mathrm{PO}_{4}, 2 \mathrm{~g}$ of $\left(\mathrm{NH}_{4}\right)_{2} \mathrm{SO}_{4}, 0.4 \mathrm{~g}$ of $\mathrm{MgSO}_{4} \cdot 7 \mathrm{H}_{2} \mathrm{O}, 2 \mathrm{~g}$ of yeast extract (Merck, Darmstadt, Germany), and $20 \mathrm{~g}$ of glucose p.a.

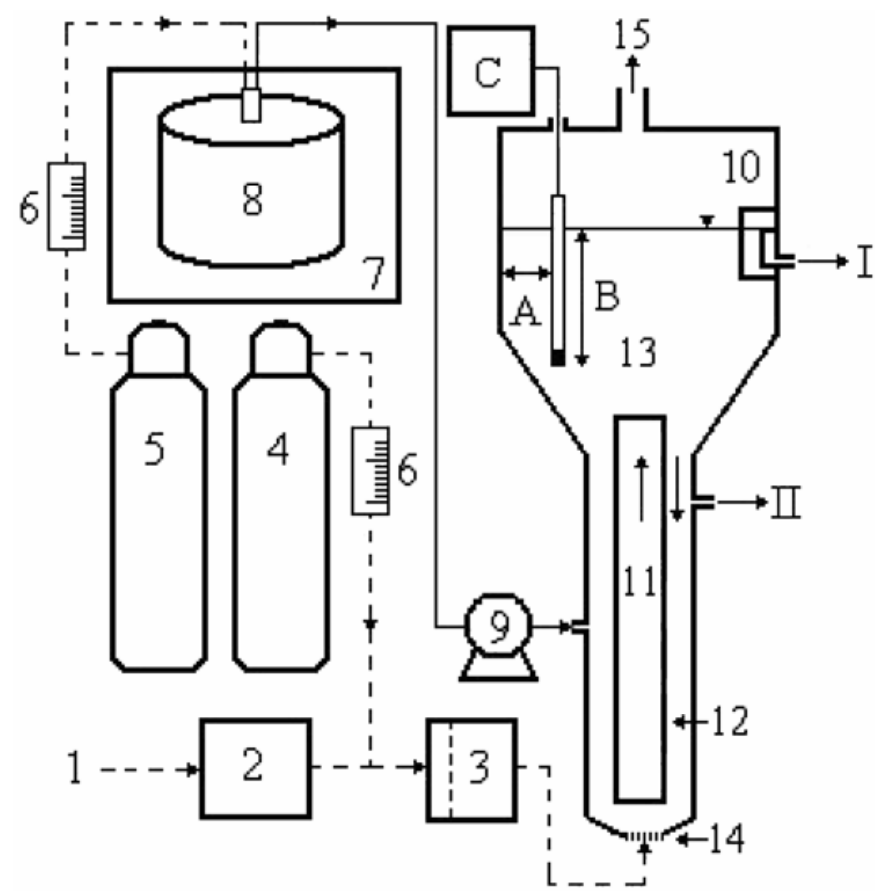

Fig. 1. Schematic diagram of the continuous immobilized cell reactor system kept in a thermostatted cold room: $1=$ air supply, $2=$ mass flow controller, $3=$ gas-sterilization filter, $4=\mathrm{CO}_{2}$ cylinder, $5=\mathrm{N}_{2}$ cylinder, $6=$ rotameters, $7=$ refrigerator, $8=$ barrel with complex model medium, $9=$ peristaltic pump, $10=$ gas-lift reactor, $11=$ riser, $12=$ downcomer, $13=$ enlarged separator zone, 14 = sparger (gas inlet), and $15=$ gas outlet; $\mathrm{I}=$ medium outflow, $\mathrm{II}=$ sampling port, $\mathrm{A}=$ distance of oxygen probe from reactor wall, $\mathrm{B}=$ depth of oxygen probe below liquid surface, and $\mathrm{C}=$ data acquisition system.
(Penta, Chrudim, Czech Republic) per liter. During the experiments focused on the aldehyde removal capacity of the immobilized cell reactor system, the aldehydes were added to CMM at the following concentrations: $100 \mu \mathrm{g}$ of 2-methyl propanal, $200 \mu \mathrm{g}$ of 3-methyl butanal, $100 \mu \mathrm{g}$ of hexanal, and $100 \mu \mathrm{g}$ of furfural (Fluka Chemie $\mathrm{GmbH}$, Steinheim, Switzerland) per liter. Barrels containing $20 \mathrm{~L}$ of CMM were sterilized at $121^{\circ} \mathrm{C}$ and $100 \mathrm{kPa}$ for $30 \mathrm{~min}$.

\section{Immobilized Cell Reactor}

The GLR used in this work was a concentric draught-tube type with an enlarged top section for degassing and a total working volume of $2.9 \mathrm{~L}$. The total height of the reactor was $76 \mathrm{~cm}$, the downcomer was $44 \mathrm{~cm}$ long, and the inside diameter was $7 \mathrm{~cm}$; the draft tube (riser) was $41 \mathrm{~cm}$ long, $3.2 \mathrm{~cm}$ in diameter, and $0.4 \mathrm{~cm}$ thick; and the cylindrical part was $8 \mathrm{~cm}$ long and $14 \mathrm{~cm}$ in diameter. The angle between the conical sector and the main body was $51^{\circ}$. Gas was injected through a sparger (perforated plate, $1 \mathrm{~cm}$ in diameter) with seven holes $(0.5 \mathrm{~mm}$ each) and placed $2.5 \mathrm{~cm}$ below the annulus of the riser. The outflow of the reactor was placed behind a sedimentation barrier, minimizing carrier losses. The whole immobilized cell reactor (ICR) was placed in a thermostatted cold room (Fig. 1). The desired gas flow (pure air or air and $\mathrm{CO}_{2}$ mixture) was adjusted with a mass flow controller (GFC17, Aalborg Instruments, Orangeburg, NY). Dry spent grains were cleaned by acidic hydrolysis $\left(3 \%\right.$ [vol/vol] $\left.\mathrm{HCl}, 2.5 \mathrm{hr}, 60^{\circ} \mathrm{C}\right)$ followed by delignification in $2 \%$ (wt/vol) $\mathrm{NaOH}\left(24 \mathrm{hr}, 30^{\circ} \mathrm{C}\right)$. Prior to use, the carrier was washed with water until a $\mathrm{pH}$ of 7 was reached and dried $\left(12 \mathrm{hr}, 60^{\circ} \mathrm{C}\right)(6)$.

\section{Starting and Operating the ICR}

The Plexiglas GLR was sterilized using sodium hypochlorite solution (2\% active chlorine) at least 4 days prior to fermentation. After draining the reactor, the sterile air supply into the GLR was started at a total flow rate of $0.25 \mathrm{~L} / \mathrm{min}$, and the GLR was washed with $30 \mathrm{~L}$ of sterile water. Prior to inoculation, the reactor was filled with sterilized slurry consisting of $40 \mathrm{~g}$ of spent grains in a dry state in $1.5 \mathrm{~L}$ of distilled water. Subsequently, the GLR was charged with CMM and inoculated with $500 \mathrm{~mL}$ of yeast cell suspension (approx. $30 \times 10^{6}$ cells $/ \mathrm{mL}$ ) grown on a rotary shaker at $20^{\circ} \mathrm{C}$ for $48 \mathrm{hr}$. After $24 \mathrm{hr}$ of batch growth, the start-up period of the ICR was initiated. The CMM was fed at a total residence time of $6.5 \mathrm{hr}$, and the temperature inside the GLR was maintained at $8^{\circ} \mathrm{C}$. Within 10 days, a fully developed yeast biofilm was formed around the spent grain particles, and afterward, the intensity of aeration was decreased by switching to an air and $\mathrm{CO}_{2}$ mixture, while the total gas flow rate was kept constant $(0.25 \mathrm{~L} / \mathrm{min})$. To prevent contamination and oxidation, CMM was kept during the whole experiment in a refrigeration unit at $4{ }^{\circ} \mathrm{C}$, while $\mathrm{N}_{2}$ was sparged into the wort barrel $(50 \mathrm{~mL} / \mathrm{min})$. The continuous system was considered to be in steady state after a period of five residence times.

\section{Determination of $k_{\mathrm{L}} a$ in a Three-Phase (Gas-Liquid-Solid) \\ Reactor}

The volumetric gas-liquid mass transfer coefficient $\left(k_{\mathrm{L}} a\right)$ in the three-phase (gas-liquid-solid) GLR used in this work was determined by the dynamic gassing-out method (2). The three-phase system in the GLR consisted of gas $\left(\mathrm{N}_{2}\right.$ or air), liquid (CMM), and solid ( $0-14 \mathrm{~g}$ of spent grains per $\mathrm{L}$ of reactor volume). The oxygen probe was placed in the enlarged top section (degassing zone) $2 \mathrm{~cm}$ from the side and $7 \mathrm{~cm}$ below the liquid surface. The measurement was conducted as follows. First, oxygen was desorbed from the liquid phase by feeding the GLR with nitrogen $(250 \mathrm{~mL} / \mathrm{min})$. When zero oxygen concentration was reached, the nitrogen flow was stopped, and air was immediately fed into the reactor $(250 \mathrm{~mL} / \mathrm{min})$. The change in oxygen concentration was measured using an oxygen probe (XB4-K/S, Gryf s.r.o., Havlíčkův Brod, Czech Republic) 
and collected using a data acquisition system (Magic XBC, Gryf s.r.o.) running on a PC. The $k_{\mathrm{L}} a$ was calculated from the slope of increasing dissolved oxygen concentration $(10,15)$. A well-mixed liquid phase was assumed, and the influence of oxygen electrode dynamics on the $k_{\mathrm{L}} a$ was neglected because the probe response time (approx. $30 \mathrm{sec}$ ) was significantly lower than $1 / k_{\mathrm{L}} a$. The obtained $k_{\mathrm{L}} a$ values were used to calculate the oxygen transfer rates (OTR) under real fermentation conditions at a known solid load $(14 \mathrm{~g} / \mathrm{L})$, partial oxygen pressure in different gas mixtures (air and $\mathrm{CO}_{2}$ ), and absorption coefficient of oxygen in CMM at $8^{\circ} \mathrm{C}(56.95 \mathrm{mg} / \mathrm{L})$.

\section{Analytical Methods}

Ethanol and glucose were analyzed by HPLC (pump LCP 4000 and column oven LCO 101, ECOM Ltd., Prague) using a $250 \times 8 \mathrm{~mm}$ column (Polymer IEX Ca form, Watrex International Inc., San Francisco) and refraction index detector (RIDK 102, Laboratorní přístroje Praha, Prague). Elution was performed with Nanopure-filtered water at $85^{\circ} \mathrm{C}$ at a flow rate of $0.7 \mathrm{~mL} / \mathrm{min}$. The flavor and aroma compounds (higher alcohols, esters, and vicinal diketones) were measured according to the current EBC recommended methods (13). The aldehydes were determined by solid-phase microextraction using on-fiber derivatization with $O$-(2,3,4,5,6-pentafluorobenzyl) hydroxylamine (PFBOA). The carbonyl compounds selectively reacted with PFBOA, and the oximes formed were desorbed into a gas chromatograph injection port $(6890 \mathrm{~N}$, Agilent Technologies, Santa Clara, CA) and quantified by mass spectrometry (5975, Agilent Technologies) (34). Cell viability was measured by counting dead cells stained with methylene blue (14). Immobilized biomass was determined according to Brányik et al (7).

Samples of free and immobilized cells were collected at the sampling port of the ICR (Fig. 1). Immobilized cells were liberated from the biocatalyst (carrier and immobilized cells) using agitation. Biocatalyst taken from the ICR was washed in running water $(4 \times 100 \mathrm{~mL})$ and agitated (2-cm magnetic bar at $200 \mathrm{rpm})$ in $50 \mathrm{~mL}$ of physiological solution $(9 \mathrm{~g}$ of $\mathrm{NaCl}$ per $\mathrm{L})$ for $20 \mathrm{~min}$. The biomass released from the carrier was used to determine viability.

\section{RESULTS AND DISCUSSION}

\section{Estimation of OTR in a Three-Phase Bioreactor}

If ethanol productivity was the only quality criterion of continuous beer fermentation, it would be relatively easy to control and optimize this process. However, during beer production, the well-balanced aroma and flavor of the final product are equally or even more important than efficient fermentation and high ethanol yield. During traditional batch beer fermentation, events such as oxygen dissolution and substrate depletion trigger the selective and sequential assimilation of individual compounds, as well as the formation of metabolic by-products, in a coordinated fashion. Therefore, beer flavor results from a mixture of by-products formed during growth phases that match up with metabolic pathways of different rates (5).

Although the immobilized and free cell populations in a continuous fermenter lack the distinct growth phases of a batch culture, optimum oxygen supply is essential for both yeast physiology and by-product formation. To avoid the often observed under- or overaeration in continuous beer fermentation systems, it was necessary to determine the $k_{\mathrm{L}} a$ under real fermentation conditions.

The $k_{\mathrm{L}} a$ was determined for a three-phase internal-loop airlift reactor with an enlarged degassing zone. Reduction of the $k_{\mathrm{L}} a$ by $65 \%$ was obtained with the introduction $14 \mathrm{~g}$ of solids (spent grains) per L compared with the two-phase system (gas-liquid) in a GLR without a carrier (Fig. 2). This is in accordance with the observations of diminishing volumetric gas-liquid mass transfer coefficients at increasing solids loading in both pneumatically and mechanically agitated air-lift reactors. The effect of solids on the $k_{\mathrm{L}} a$ can be explained by bubble coalescence, which results in a smaller gas-liquid interfacial area $(a)$. The merging of bubbles in the draft tube most probably was caused by the presence of solid particles decreasing the flux area $(10,15)$.

The positional dependence of oxygen transfer is a characteristic feature of GLR fermenters (9). Despite the fact that the $k_{\mathrm{L}} a$ measurement presented in this paper was carried out at only one location in the GLR, i.e., in its top section, we assume that for the operational regime in this reactor the locally estimated $k_{\mathrm{L}} a$ values can be considered satisfactory. This statement is based on the fact that the positional $k_{\mathrm{L}} a$ differences diminish with decreasing superficial gas velocity (27). The superficial gas velocity in our reactor at a total gas flow rate of $0.25 \mathrm{~L} / \mathrm{min}$ was $0.0052 \mathrm{~m} / \mathrm{sec}$; therefore, we assume that the presented $k_{\mathrm{L}} a$ values (Fig. 2) can be considered constant in the entire reactor.

The OTR during real fermentation experiments was calculated using the $k_{\mathrm{L}} a\left(0.977 \pm 0.49 \mathrm{hr}^{-1}\right)$ determined for the solid loading of $40 \mathrm{~g}$ of dry spent grains per reactor volume $(14 \mathrm{~g} / \mathrm{L})$. The influence of additional biomass (solids) and organic compounds (e.g., alcohols) present in fermented media was neglected. Different OTR were achieved by changing the composition of the driving gas (air and $\mathrm{CO}_{2}$ ), which resulted in different partial oxygen pressure in the gas mixture.

\section{Continuous ICR System}

The start-up period of the continuous experiments in the GLR in which CMM was used as a feed gave rise to the spontaneous attachment of brewing yeast to the surfaces of spent grain particles (4). This initial phase was characterized by an $8^{\circ} \mathrm{C}$ fermentation temperature, $6.5-\mathrm{hr}$ residence time, and OTR of $12.35 \mathrm{mg} / \mathrm{L} / \mathrm{hr}$, which was achieved by sparging pure air at $250 \mathrm{~mL} / \mathrm{min}$ into the GLR. The immobilized biomass load on the surfaces of spent grain particles reached its plateau after an approx. 10-day start-up period and then remained constant $\left(X_{i m}=0.75 \pm 0.09 g_{I B} / g_{C}\right.$, where $I B=$ dry immobilized biomass and $C=$ dry carrier). When the yeast biofilm buildup finished, the composition of the driving gas was changed from pure air to an air and $\mathrm{CO}_{2}$ mixture. After reaching steady-state conditions in the ICR at a given driving gas composition, a step-wise shift to lower air content in the driving gas was carried out. The changes in driving-gas composition decreased neither the biomass load nor the viability of the yeast biofilm around the spent grain particles. Over the course of the continuous experiment, both the dead immobilized and free cell numbers in the

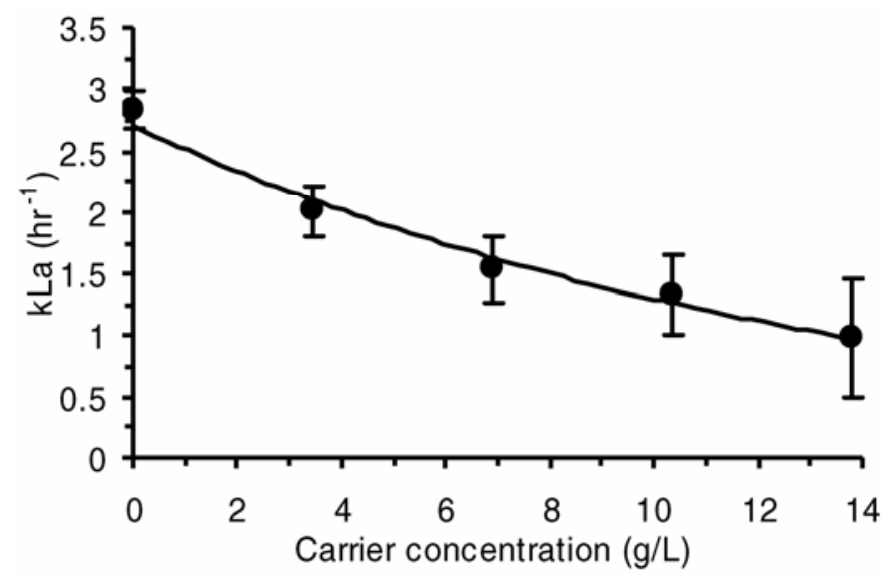

Fig. 2. Volumetric oxygen mass transfer coefficient $\left(k_{\mathrm{L}} a\right.$; an average of five measurements; error bars represent average deviations) versus carrier (spent grains) concentration in a three-phase (gas-liquid-solid) gas-lift reactor. 
ICR system remained constant $(6.1 \pm 1.5 \%)$; therefore, the effect of ageing on flavor formation could be neglected. The concentration of free cells, liberated or outgrown from the yeast biofilm, increased from 0.45 to $1.6 g_{D W} / \mathrm{L}(D W=$ dry weight $)$ following the increase in oxygen supply from the lowest to the highest aeration intensities.

\section{Influence of Oxygen Supply on Formation of Volatiles}

The experiments that studied the influence of oxygen supply on the conversion of flavor-active compounds were carried out under conditions $\left(8^{\circ} \mathrm{C}\right.$, residence time $6.5 \mathrm{hr}$ ) that led to $0.5-1.0 \%$ (vol $\left./ \mathrm{vol}\right)$ ethanol content in fermented CMM. The concentrations of flavoractive compounds presented in this paper are those obtained after dilution of fermented CMM with distilled water to the maximum ethanol concentration ( $0.5 \%$ by volume) permitted in alcohol-free beers.

The amount of oxygen delivered into the GLR noticeably stimulated the formation of higher alcohols (Fig. 3). This is not surprising, because higher alcohols are produced during beer fermentation

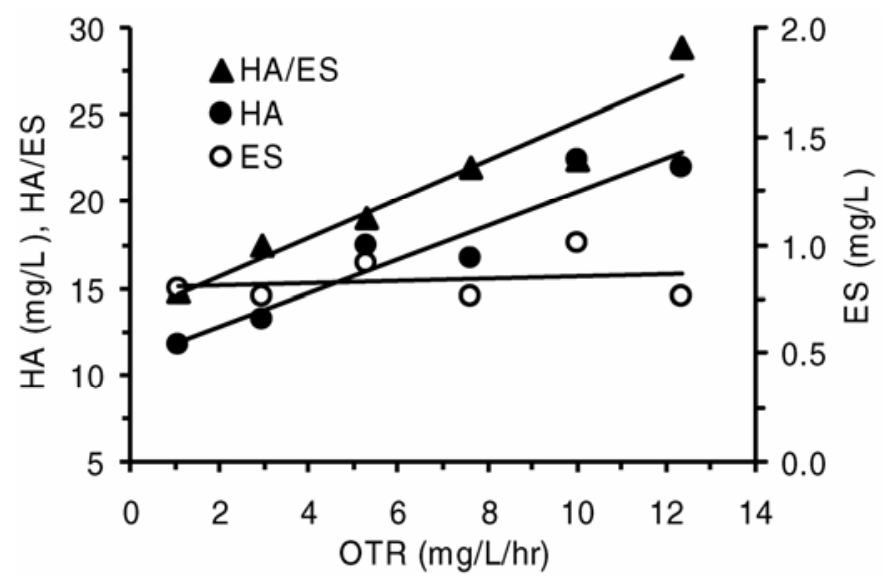

Fig. 3. Influence of oxygen transfer rate (OTR) on the concentration of total higher alcohols (HA), total esters (ES), and their mutual ratio (HA/ES) at $0.5 \%$ ( $\mathrm{vol} / \mathrm{vol})$ ethanol in the fermented complex model medium. from 2-oxo acids that arise from either carbohydrate or amino acid metabolism. Consequently, interventions based on the stimulation of metabolic activity (e.g., aeration, temperature, immobilization, reactor design, etc.) usually enhance the formation of higher alcohols $(7,17,29)$. The concentrations of total higher alcohols (HA) and their individual components were compared with these compounds found in three commercially available alcohol-free beers produced by traditional batch fermentation (Table I).

The total ester (ES) concentrations in both the fermented CMM from the ICR $(0.83 \mathrm{mg} / \mathrm{L})$ and commercial alcohol-free beers produced by traditional batch fermentation $(0.17-1.82 \mathrm{mg} / \mathrm{L})$ were in the same range (Table I). Simultaneously, the ES formation in the ICR seemed to be independent of OTR (Fig. 3). Some researchers regard ester formation as a metabolic pathway that uses superfluous substrates (acyl-CoA and alcohols) under nongrowing conditions (29). According to these researchers, higher wort aeration can affect ester synthesis both negatively, through reduced availability of acetyl-CoA (used for growth and lipid synthesis) and inhibition of alcohol acyltransferases, and positively, through the increased availability of higher alcohols. Thus, it can be assumed that the final ester formation in the ICR resulted from the interplay of both enhancing and inhibiting factors. In addition to process conditions (aeration), the ester concentration also depends on cell physiology, immobilization method, yeast strain, and wort composition (12). Therefore, ester formation can be considered a sensitive process that is difficult to control and predict due to numerous factors that influencing it.

With regard to the balance of beer flavor, it is the HA/ES ratio that is particularly important. In regular beers, the HA/ES ratio is considered favorable at approx. 3:1 (18). Approaching the same values in alcohol-free beers would be considered an improvement in sensorial quality. Therefore, the best HA/ES ratio achieved in the continuous system (14.2:1) was the one at the lowest oxygen supply level (Table I). The same quality criterion (HA/ES) determined for three commercial alcohol-free beers produced by a traditional shortbatch fermentation method was in the range of 9.3:1 to 55:1, rendering the minimum HA/ES ratio obtained in our experiments satisfactory. Moreover, the lowest OTR ( $1 \mathrm{mg}$ of $\mathrm{O}_{2}$ per L per hr) achieved in a laboratory-scale GLR could be decreased further in large-scale reactors, allowing better control of flavor compound formation.

TABLE I

Flavor-Active Compounds in Complex Model Medium (CMM) from a Continuous Immobilized Cell Reactor (ICR) System and in Three Commercial Alcohol-free Beers Produced by Traditional Industrial Batch Fermentation ${ }^{\mathrm{a}}$

\begin{tabular}{|c|c|c|c|c|c|}
\hline Parameter & CONT $^{b}$ & Comm 1 & Comm 2 & Comm 3 & Threshold $^{\mathrm{c}}$ \\
\hline Ethanol (\%, vol/vol) & 0.50 & $\leq 0.50$ & $\leq 0.50$ & $\leq 0.50$ & 1.77 \\
\hline$n$-Propanol (mg/L) & 1.60 & 2.00 & 2.70 & 2.10 & 800 \\
\hline Isobutanol (mg/L) & 1.60 & 1.80 & 1.00 & 3.85 & 200 \\
\hline Amyl alcohols (mg/L) & 8.60 & 7.65 & 5.60 & 10.95 & 70 \\
\hline Total higher alcohols (mg/L) & 11.80 & 11.45 & 9.30 & 16.90 & $\ldots$ \\
\hline Ethyl acetate $(\mathrm{mg} / \mathrm{L})$ & 0.58 & 0.78 & 0.13 & 1.44 & 30 \\
\hline Amyl acetates (mg/L) & 0.02 & 0.06 & 0.02 & 0.35 & 1.20 \\
\hline Ethyl caproate (mg/L) & 0.01 & 0.01 & 0.01 & 0.01 & 0.23 \\
\hline Ethyl caprylate (mg/L) & 0.22 & 0.01 & 0.01 & 0.02 & 0.90 \\
\hline Total esters $(\mathrm{mg} / \mathrm{L})$ & 0.83 & 0.86 & 0.17 & 1.82 & $\ldots$ \\
\hline Total higher alcohols/total esters ratio & 14.20 & 13.70 & 54.70 & 9.30 & $\ldots$ \\
\hline Acetaldehyde (mg/L) & 8.50 & 6.90 & 7.40 & 0.70 & 10 \\
\hline Hexanal $(\mu \mathrm{g} / \mathrm{L})$ & 0.20 & 0.20 & 0.10 & 0.40 & 300 \\
\hline 2-Methyl propanal ( $\mu \mathrm{g} / \mathrm{L})$ & 1.70 & 0.30 & 1.60 & 4.30 & 1000 \\
\hline 3-Methyl butanal $(\mu \mathrm{g} / \mathrm{L})$ & 8.70 & 1.60 & 7.40 & 6.80 & 600 \\
\hline Furfural $(\mu \mathrm{g} / \mathrm{L})$ & 1.50 & 2.70 & 3.60 & 5.90 & 150,000 \\
\hline Total aldehydes $(\mu \mathrm{g} / \mathrm{L})$ & 12.10 & 4.80 & 12.70 & 17.40 & $\ldots$ \\
\hline Vicinal diketones $(\mathrm{mg} / \mathrm{L})^{\mathrm{d}}$ & 0.06 & 0.05 & 0.08 & 0.03 & 0.15 \\
\hline
\end{tabular}

${ }^{a}$ Comm 1, 2, and 3 = commercial alcohol-free beers available in the Czech Republic.

${ }^{\mathrm{b}} \mathrm{CMM}$ fermented (oxygen transfer rate: $1 \mathrm{mg}$ of $\mathrm{O}_{2}$ per L per hr; temperature: $8^{\circ} \mathrm{C}$; residence time: $6.5 \mathrm{hr}$ ) in the ICR and diluted to $0.5 \%$ (vol/vol) ethanol.

c Flavor thresholds (20).

d 2,3-Butanedione and 2,3-pentanedione. 


\section{Carbonyl Compounds}

Beer aldehydes arise mainly during wort production (mashing and boiling), whereas the contribution of aldehyde formation during fermentation is considered small. Instead, aldehydes are reduced extensively during fermentation by brewing yeast (22). The amount of different aldehydes formed during fermentation, with no aldehyde addition into CMM, determined at an ethanol content of $0.5 \%$ (vol $/ \mathrm{vol}$ ) (OTR: $1 \mathrm{mg}$ of $\mathrm{O}_{2}$ per L per hr, temperature: $8^{\circ} \mathrm{C}$ ) ranged from 0.8 to $5.1 \mu \mathrm{g} / \mathrm{L}$. In view of the CMM supplementation with individual aldehydes (100-200 $\mu \mathrm{g} / \mathrm{L})$, the contribution of aldehyde formation by yeast metabolism to the final aldehyde content in CMM can be neglected.

Wort aldehyde reduction during traditional beer fermentation does not represent an important flavor issue due to the long contact time (several weeks) between yeast and wort aldehydes. In contrast, aldehyde reduction efficiency during alcohol-free beer fermentation in a continuous system (contact time of several hours) provokes concern and represents an important measure in the evaluation of the process.

A significant reduction in the concentration of aldehydes added to CMM was observed during fermentation in the ICR. Total aldehyde removal efficiency varied from 86 to $95 \%$, with higher values obtained at lower aerations (Fig. 4). These observations of aldehyde reduction agree with former results that found that fermentative metabolism is more efficient with regard to aldehyde reduction and that the linear saturated aldehydes are the most rapidly reduced (11). However, it can be assumed that a significant portion of the aldehydes were not reduced by microbial metabolism but were removed chemically through binding to amino acids or proteins in CMM (24).

The aldehyde reduction capacity of the immobilized and free biomass inside the ICR is expected to be sufficient to reduce the aldehyde content of real wort used for alcohol-free beer production. This belief is based on the fact that the total aldehyde content of an $8 \%$ (wt/vol) wort (brewed at the ICT microbrewery) was, on average, $45 \%$ lower than that of the CMM applied in this work (data not shown). The aldehyde reduction efficiency of cells in the ICR was also better than or equal to that from the continuous system with silicon carbide and DEAE-cellulose used as immobilization materials (11).

Conversely to the aforementioned aldehydes, the formation of carbonyl compounds with sensorial activity, such as vicinal diketones (VDK: 2,3-butanedione and 2,3-pentanedione) and acetaldehyde, is linked to fermentation and the active growth phase of yeast $(3,35)$. The concentrations of VDK and acetaldehyde were

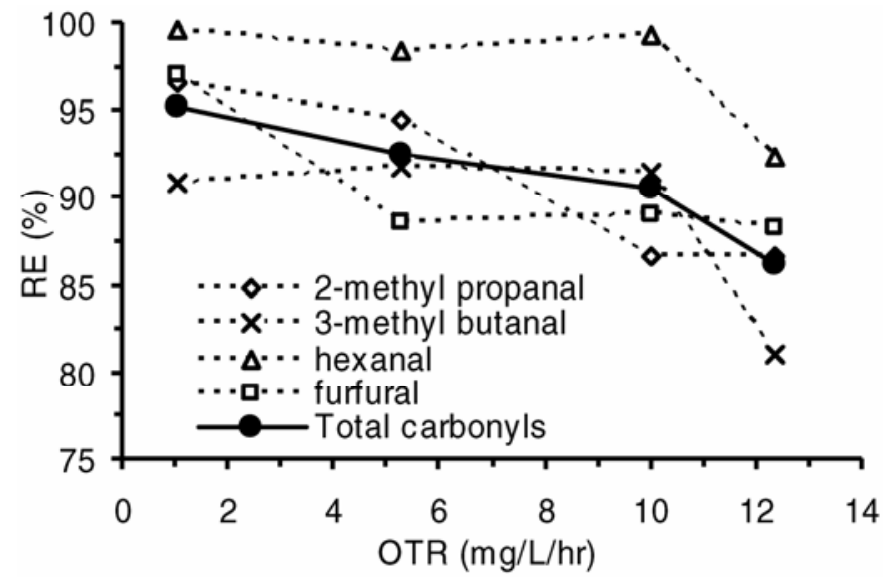

Fig. 4. Reduction efficiency (RE) of individual and total aldehydes versus oxygen transfer rate (OTR) at a constant fermentation temperature $\left(8^{\circ} \mathrm{C}\right)$ and residence time $(6.5 \mathrm{hr})$ in the immobilized cell reactor system.
0.06 and $8.5 \mathrm{mg} / \mathrm{L}$, respectively, in CMM fermented at the lowest OTR ( $1 \mathrm{mg}$ of $\mathrm{O}_{2}$ per L per hr) and diluted to $0.5 \%$ (vol/vol) ethanol. As a result, the VDK content does not represent a serious flavor issue, because the taste threshold limit $(0.15 \mathrm{mg} / \mathrm{L})$ is much higher (20). On the other hand, the acetaldehyde content in diluted CMM approached the taste threshold limit of $10 \mathrm{mg} / \mathrm{L}$ (Table I), and its formation was stimulated further by increasing OTR, leading to a concentration as high as $23 \mathrm{mg} / \mathrm{L}$ at $12 \mathrm{mg}$ of $\mathrm{O}_{2}$ per $\mathrm{L}$ per hr. However, if necessary the higher acetaldehyde formation could be decreased by selection or construction of a yeast strain with reduced acetaldehyde production (36). Of course, this approach counts for other flavor substances as well. We can only speculate about the extent to which the CMM composition influences the formation of acetaldehyde and other flavor substances based on other experiments (8); therefore, further trials with real wort will have to be carried out.

\section{CONCLUSIONS}

Generally, it can be concluded that aeration is an important process parameter that enables control of flavor formation during continuous alcohol-free beer fermentation. The following conclusions can be drawn regarding the influence of oxygen supply on the flavor composition of a continuously fermented model medium that mimics the production of alcohol-free beer:

1) The total HA/ES ratio increased with higher oxygen supply. The adjustment of oxygen supply, based on the determination of $k_{\mathrm{L}} a$ in a three-phase GLR, was not only suitable for fine-tuning the HA/ES ratio in the studied system (ICR) but also could be transferable between different systems or could serve for estimation of aeration demands during scale-up studies.

2) The concentration of total HA and ES, as well as the HA/ES ratio, found in the continuously fermented model medium with optimized oxygen supply was comparable to those found in three commercial alcohol-free beers.

3) The wort aldehyde reduction capacity of the ICR is assumed to be sufficient based on the fact that the reduction of total aldehydes, added in excess to model medium, was very efficient (85-95\%).

4) The concentration of flavor-active compounds, such as VDK and acetaldehyde, was fermented in the CMM under optimized conditions below the taste threshold.

\section{ACKNOWLEDGMENTS}

We thank the Czech Grant Agency (grant 104/06/1418) and MŠMT (MSM 6046137305, Czech Republic) for financial support.

\section{LITERATURE CITED}

1. Almeida, C., Brányik, T., Moradas-Ferreira, P., and Teixeira, J. A. Use of two different carriers in a packed bed reactor for endopolygalacturonase production by a yeast strain. Process Biochem. 40:1937-1942, 2005.

2. Blažej, M., Annus, J., and Markoš, J. Comparison of gassing out and pressure-step dynamic methods for $\mathrm{k}_{\mathrm{L}}$ a measurement in an airlift reactor with internal loop. Chem. Eng. Res. Des. 82:1375-1382, 2004.

3. Brányik, T., Silva, D. P., Vicente, A. A., Lehnert, R., Almeida e Silva, J. B., Dostálek, P., and Teixeira, J. A. Continuous immobilized yeast reactor system for complete beer fermentation using spent grains and corncobs as carrier materials. J. Ind. Microbiol. Biotechnol. 33:10101018, 2006.

4. Brányik, T., Vicente, A., Kuncová, G., Podrazký, O., Dostálek, P., and Teixeira, J. Growth model and metabolic activity of brewing yeast biofilm on the surface of spent grains: A biocatalyst for continuous beer fermentation. Biotech. Prog. 20:1733-1740, 2004. 
5. Brányik, T., Vicente, A. A., Dostálek, P., and Teixeira, J. A. A review of flavour formation in continuous beer fermentations. J. Inst. Brew. 114:3-13, 2008.

6. Brányik, T., Vicente, A. A., Machado Cruz, J. M., and Teixeira, J. A. Spent grains-A new support for brewing yeast immobilization. Biotech. Lett. 23:1073-1078, 2001.

7. Brányik, T., Vicente, A. A., Machado Cruz, J. M., and Teixeira, J. A. Continuous primary fermentation of beer with yeast immobilized on spent grains-The effect of operational conditions. J. Am. Soc. Brew. Chem. 62:29-34, 2004.

8. Chen, T., Zhang, L., and Zhu, W. High-ratio adjunct brewing with a supplement of yeast hydrolysate. J. Am. Soc. Brew. Chem. 64:202-205, 2006.

9. Chisti, Y. Airlift Bioreactors. Elsevier Applied Science, London, 1989.

10. Chisti, Y., and Jauregui-Haza, U. J. Oxygen transfer and mixing in mechanically agitated airlift bioreactors. Biochem. Eng. J. 10:143-153, 2002.

11. Debourg, A., Laurent, M., Goossens, E., Borremans, E., Van de Winkel, L., and Masschelein, C. A. Wort aldehyde reduction potential in free and immobilized yeast systems. J. Am. Soc. Brew. Chem. 52:100-106, 1994.

12. Dufour, J. P., Malcorps, P., and Silcock, P. Control of ester synthesis during brewery fermentation. In: Brewing Yeasts Fermentation Performance. K. Smart, ed. Blackwell Science Ltd., Oxford. Pp. 213-233, 2003.

13. European Brewery Convention. Analytica-EBC. Section 9 Beer Method 9.24.1 Vicinal diketones in beer: Spectrophotometric method; Beer Method 9.39. Dimethyl sulphide and other lower boiling point volatile compounds in beer by gas chromatography. Verlag Hans Carl Getranke Fachverlag, Nürnberg, Germany, 2000.

14. European Brewery Convention. Analytica-Microbiologica EBC. Section 3 Beer Method 3.2.1.1 Methylene blue staining. Verlag Hans Carl Getranke Fachverlag, Nürnberg, Germany, 2000.

15. Freitas, C., and Teixeira, J. A. Oxygen mass transfer in a high solids loading three-phase internal-loop airlift reactor. Chem. Eng. J. 84:57$61,2001$.

16. Fujii, T., Kobayashi, O., Yoshimoto, H., Furukawa, S., and Tamai, Y. Effect of aeration and unsaturated fatty acids on expression of the Saccharomyces cerevisiae alcohol acetyltransferase gene. Appl. Environ. Mircobiol. 63:910-915, 1997.

17. García, A. I., García, L. A., and Díaz, M. Fusel alcohols production in beer fermentation processes. Process Biochem. 29:303-309, 1994.

18. Kunze, W., and Mieth, H. O. Technology Brewing and Malting. VLB, Berlin. Pp. 330, 437-446, 1996.

19. Linko, M., Virkajärvi, I., Pohjala, N., Lindborg, K., Kronlöf, J., and Pajunen, E. Main fermentation with immobilized yeast-A breakthrough? Proc. Congr. Eur. Brew. Conv. 26:385-394, 1997.

20. Meilgaard, M. C. Flavor chemistry of beer. Part II: Flavor and threshold of 239 aroma volatiles. Tech. Q. Master Brew. Assoc. Am. 12:151$168,1975$.

21. Norton, S., and D'Amore, T. Physiological effects of yeast immobilization: Application for brewing. Enzyme Microb. Technol. 16:365-375,
1994.

22. Peppard, T. L., and Halsey, S. A. Malt flavour-Transformation of carbonyl compounds by yeast during fermentation. J. Inst. Brew. 87: 386-390, 1981.

23. Perpete, P., and Collin, S. Contribution of 3-methylthiopropionaldehyde to the worty flavor of alcohol-free beers. J. Agric. Food Chem. 47: 2374-2378, 1999.

24. Perpete, P., and Collin, S. Fate of the worty flavors in a cold contact fermentation. Food Chem. 66:359-363, 1999.

25. Perpete, P., and Collin, S. State of the art in low-alcohol beer production. Cerevisia 24:27-33, 1999.

26. Romano, P., Suzzi, G., Comi, G., and Zironi, R. Higher alcohol and acetic-acid production by apiculate wine yeasts. J. Appl. Bacteriol. 73: 126-130, 1992.

27. Russell, A. B., Thomas, C. R., and Lilly, M. D. Oxygen transfer measurements during yeast fermentations in a pilot scale airlift fermenter. Bioprocess Eng. 12:71-79, 1995.

28. Shindo, S., and Tachibana, T. Production of bioethanol from spent grain, a by-product of beer production. Tech. Q. Master Brew. Assoc. Am. 43: 189-193, 2006.

29. Šmogrovičová, D., and Dömény, Z. Beer volatile by-product formation at different fermentation temperatures using immobilized yeasts. Process Biochem. 34:785-794, 1999.

30. Snoek, I. S. I., and Steensma, H. Y. Factors involved in anaerobic growth of Saccharomyces cerevisiae. Yeast 24:1-10, 2007.

31. Van De Winkel, L., Van Beveren, P. C., Borremans, E., Goossens, E., and Masschelein, C. A. High performance immobilized yeast reactor design for continuous beer fermentation. Proc. Congr. Eur. Brew. Conv. 24:307-314, 1993.

32. Van Iersel, M. F. M., Meersman, E., Swinkels, W., Abee, T., and Rombouts, F. M. Continuous production of non-alcohol beer by immobilized yeast at low temperature. J. Ind. Microbiol. 14:495-501, 1995.

33. Verstrepen, K. J., Derdelinckx, G., Dufour, J. P., Winderickx, J., Thevelein, J. M., Pretorius, I. S., and Delvaux, F. R. Flavor-active esters: Adding fruitiness to beer. J. Biosci. Bioeng. 6:110-118, 2003.

34. Veselý, P., Lusk, L., Basařová, G., Seabrooks, J., and Ryder, D. Analysis of aldehydes in beer using solid-phase microextraction with onfiber derivatization and gas chromatography/mass spectrometry. J. Agric. Food Chem. 51:6941-6944, 2003.

35. Virkajärvi, I., Lindborg, K., Kronlöf, J., and Pajunen, E. Effects of aeration on flavor compounds in immobilized primary fermentation. Monatsschr. Brauwiss. 52:9-12, 25-28, 1999.

36. Wang, D., Sun, J., Zhang, W., Jia, F., Yang, Y., Lin, Z., Feng, J., and Pavlovic, M. Disruption of brewer's yeast alcohol dehydrogenase II gene and reduction of acetaldehyde content during brewery fermentation. J. Am. Soc. Brew. Chem. 64:195-201, 2006.

37. Yamauchi, Y., Okamoto, T., Murayama, H., Nagara, A., Kashihara, T., Yoshida, M., and Nakanishi, K. Rapid fermentation of beer using an immobilized yeast multistage bioreactor system: Balance control of extract and amino acid uptake. Appl. Biochem. Biotechnol. 53:245-259, 1995. 